\title{
Cytokinins Effect on Protein and Chloro- phyll Content of Big Bluestem Leaves
}

GENE TOWNE AND CLENTON OWENSBY

\section{Abstract}

Four concentrations of the synthetic cytokinin benzyladenine (BA) were applied to ungrazed tallgrass prairie near Manhattan, Kans., in 1979 on 4 biweekly dates beginning in mid-June. Changes in chlorophyll and crude protein content of big bluestem (Andropogon gerardi Vitman) leaves from the different treatments were monitored weekly from August until early October. BA did not significantly delay chlorophyll breakdown in big bluestem, but leaves sprayed with $5 \mathrm{ppm}$ BA contained higher mean chlorophyll contents throughout the sampling period than leaves from other treatments. Big bluestem receiving 5,20, and 40 ppm BA applied in July had significantly more crude protein than untreated leaves, but $10 \mathrm{ppm}$ BA had no effect on leaf protein content. Applying B A in mid-June was ineffective in maintaining high crude protein levels, regardless of concentration. BA did not alter protein or total nonstructural carbohydrate content in big bluestem rhizomes, indicating that it had no deleterious effect on internal nutrient reserve cycles. Applying $5 \mathrm{ppm} \mathrm{BA}$ in either mid- or late-July significantly increased herbage yields the next year in comparison with yields of untreated plots.

Forage quality of range plants rapidly decreases with increasing maturity. In tallgrass prairie, protein content falls below the subsistence level required for cattle about mid-July (Rao et al. 1973). At that time, organelles are being broken down and constituent materials exported from senescing leaves to other parts of the plant. Delaying translocation of metabolites from leaves could provide higher forage quality to grazing a nimals when nutritive values normally are declining.

Richmond and Lang (1957) initially reported that exogenous cytokinins could delay senescence onset in detached leaves. Although plant senescence is a complex syndrome of biochemical and physiological changes, the antisenescent effect of cytokinins has generally been attributed, in whole or in part, to retarding chlorophyll loss, inhibiting protein degradation, preventing effluent carbohydrate translocation, and mobilizing metabolites. Most researchers who confirmed cytokinin-induced senescence deferral used excised leaves in the dark. The physiological response of cytokinins in vivo, however, are often less conspicuous and dramatic than in vitro, so the antisenescent role of cytokinins generally has been relegated to tissue cultures and post-harvest preservation of horticultural products.

The potential for manipulating plant development was demonstrated by Fletcher (1969) when he discovered that exogenous cytokinins could retard senescence in intact bean (Phaseolus vulgaris) leaves. Since then, other in vivo greenhouse studies have confirmed that phenomenon, but there is little diversity in plant species examined. We suspected that field applications of a synthetic cytokinin could delay senescence onset in perennial grasses.

The senescent leaf becomes a major source of nitrogen following protein hydrolysis and and redistribution throughout the plant. In annuals, nutrients remobilized from senescing leaves are transiocated acropetally for seed development. Dalling et al. (1976) reported that $80 \%$ of the nitrogen in wheat (Triticum aestivum)

\footnotetext{
Authors are research assistant and research range scientist, Department of Agronomy, Kansas State University, Manhattan.

This report is contribution No. 81-426-j Department of Agronomy, Kansas Agricultural Experiment Station, Manhattan 66506.

Manuscript received June $8,1981$.
}

grain originated from senescing leaves. But in perennial grasses, $\mathbf{N}$ and other metabolites are mobilized to storage organs for recycling (Weinmann 1942). McKendrick et al. (1975) reported that $18 \%$ of the total annual $\mathrm{N}$ requirement for growth in big bluestem (Andropogon gerardi Vitman) and indiangrass [Sorghastrum nutans (L.) Nash] came from an internal nitrogen reserve. Thus, manipulating senescence with exogenous cytokinins could alter internal nutrient cycling to the extent that it lowered overwintering survival and herbage production the next growing season.

\section{Study Site and Methods}

The study area is on Kansas State University pastures in the northern Flint Hills near Manhattan. Average annual precipitation is $85 \mathrm{~cm}$. Rainfall during the 1979 May-September growing season was $39 \mathrm{~cm}, 30 \%$ below the 50-year average. Moisture in the 1980 growing season was $50 \%$ below average, and temperatures exceeded $38^{\circ} \mathrm{C}$ on 35 days.

Soil at the study site is a Benfield-Florence complex in the Udic Argiustolls subgroup of the Mollisols. That loamy upland range site has well-drained, moderately deep, silty clay loams and cherty silt loams overlying a heavy silty clay loam subsoil.

Botanical census for the study area conducted in 1979 by the modified step-point technique (Owensby 1973) indicated typical vegetation for native tallgrass prairie, with big bluestem and indiangrass comprising over $50 \%$ of the total vegetation. The area has been burned annually in late-spring, and in 1978 the study site was fenced to exclude livestock.

Benzyladenine (BA) was dissolved in $25 \mathrm{~mL}$ of $95 \%$ ethanol, heated, and mixed with distilled water. That cytokinin stock solution was diluted into $10 \mathrm{~L}$ aliquots of $5,10,20$, and $40 \mathrm{ppm} \mathrm{BA}$, each containing $10 \mathrm{ml}(0.1 \%)$ Tween-20 surfactant. All mixtures were formulated 1 day before being applied.

The site was partitioned into $4.3 \mathrm{~m} \times 6.4 \mathrm{~m}$ plots separated by 0.6 $\mathrm{m}$ alleys that were intermittently mowed throughout the growing season. Entire plots received approximately $3 \mathrm{~L}$ of one of the 4 concentrations of BA via pressurized handsprayer at biweekly intervals from mid-June until late-July 1979. Each treatment was replicated 3 times, and there were 6 untreated (control) plots in the completely randomized design.

Beginning the first week of August, and every week thereafter until October, big bluestem culms within $15 \mathrm{~cm}$ on either side of a line through the width of each plot were clipped $2 \mathrm{~cm}$ above ground level. Each week the line was systematically moved in the plot to prevent sampling any previously clipped plants.

One-third of the big bluestem harvested from each plot was placed into a plastic bag, cooled in an ice chest, and stored in a freezer for chlorophyll analysis. The remaining portion of the sample was dried in a forced-air drycr $\left(60^{\circ} \mathrm{C}\right)$, ground through a 1-mm mesh screen, and stored in sealed containers for nitrogen analysis. At least 10 big bluestem rhizomes from each plot were collected in December 1979, along previously unclipped transects. After cold-water washing, rhizomes were oven-dried for 5 days at $60^{\circ} \mathrm{C}$, ground in a Wiley mill ( $1-\mathrm{mm}$ mesh screen), and stored in sealed bottles for nitrogen and total nonstructural carbohydrate (TNC) analyses.

Chlorophyll from the frozen leaf samples was extracted with acetone and measured spectrophotometrically (Arnon 1949). Micro-kjeldahl nitrogen $(\mathrm{N})$ was determined colorimetrically for all leaf and rhizome samples, and crude protein estimated by $\mathrm{N} X$ 6.25. TNC concentration was measurcd for rhizome samples by enzyme extraction and copperiodometric titration (Smith 1969). 
Weekly clipping of big bluestem plants within each plot precluded measuring herbage yields for 1979. But after the 1980 growing season, we determined total herbage production from each treatment by clipping all species from $30.406-\mathrm{m}^{2}$ quadrats to ground level in every plot. Herbage was oven-dried and reported as kilograms dry matter per hectare.

Data were analyzed by analysis of variance, and probability of differences among treatment means was reported as $\hat{\alpha}$. Linear contrasts on cytokinin concentration and date of application also were calculated. Cytokinin concentration and date-of-application interaction means were separated by probability levels without regard to $F$-ratios from the analysis of variance.

\section{Results and Discussion}

\section{Chlorophyll Content}

As expected, chlorophyll content in untreated big bluestem leaves progressively declined each week (Fig. 1). There was no difference, however, in chlorophyll content between BA-treated and untreated leaves $(\hat{\alpha}=0.16)$. Although not statistically significant, leaves treated with $5 \mathrm{ppm}$ BA had the highest mean chlorophyll content of any treatment throughout the sampling period.

Contrary to our findings, other studies on intact plants have shown that exogenous cytokinins effectively retard chlorophyll degradation. In bean plants, BA applied at any developmental stage delayed chlorophyll loss (Fletcher 1969). Naito et al. (1978) observed that BA increased leaf chlorophyll content when applied to intact bean plants at early or middle phenological stages, and delayed chlorophyll breakdown when applied in late stages.

\section{Crude Protein Content}

Crude protein content was generally higher in big bluestem leaves receiving exogenous cytokinin, but the difference depended on concentration and application date. Leaves treated with any BA concentration except $10 \mathrm{ppm}$ had significantly more protein than leaves of untreated plants (Fig. 2). Big bluestem treated with $5 \mathrm{ppm}$ BA had higher crude protein levels than plants receiving other cytokinin treatments $(\hat{\alpha}<0.01)$.

Averaged over all sampling weeks, big bluestem treated with BA any time in July had higher protein content $(\hat{\alpha}<0.05)$ than untreated plants. The ineffectiveness of mid-June treatments suggests that young nonsenescing leaves have an adequate endogenous cytokinin content. As plants mature and a pproach the onset of senescence, exogenous BA may evoke its antisenescent effect by substituting for deficient internal cytokinins. Richmond et al.

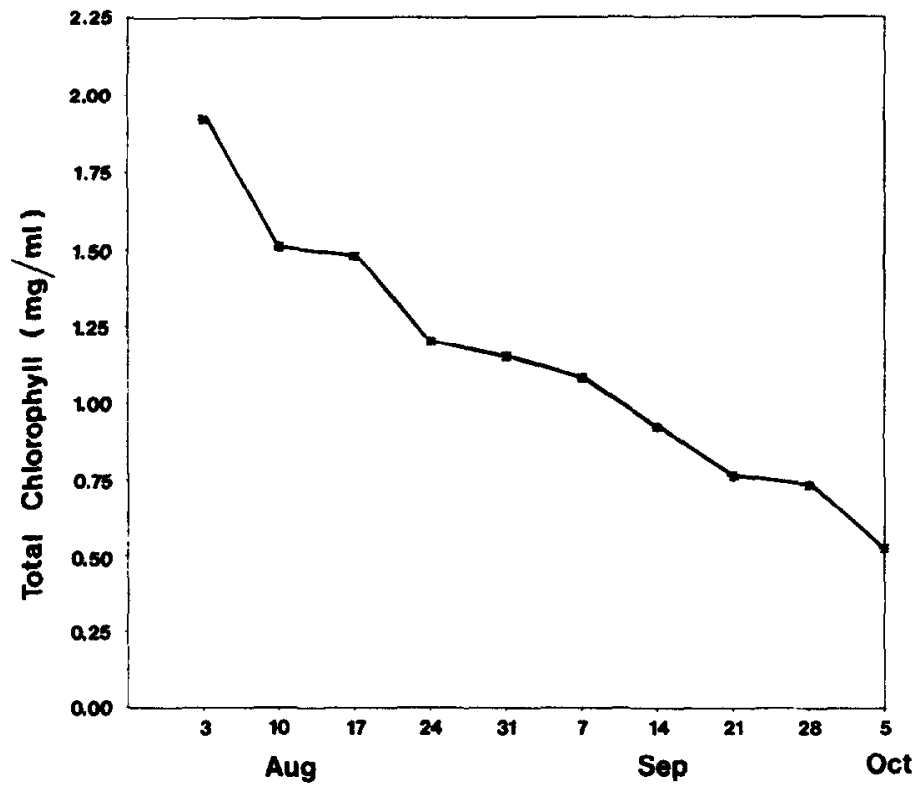

Fig. 1. Chlorophyll decline in untreated big bluestem leaves from 1 Aug. through 5 Oct. 1979 on loamy upland study site in Flint Hills near Manhattan, Kans.

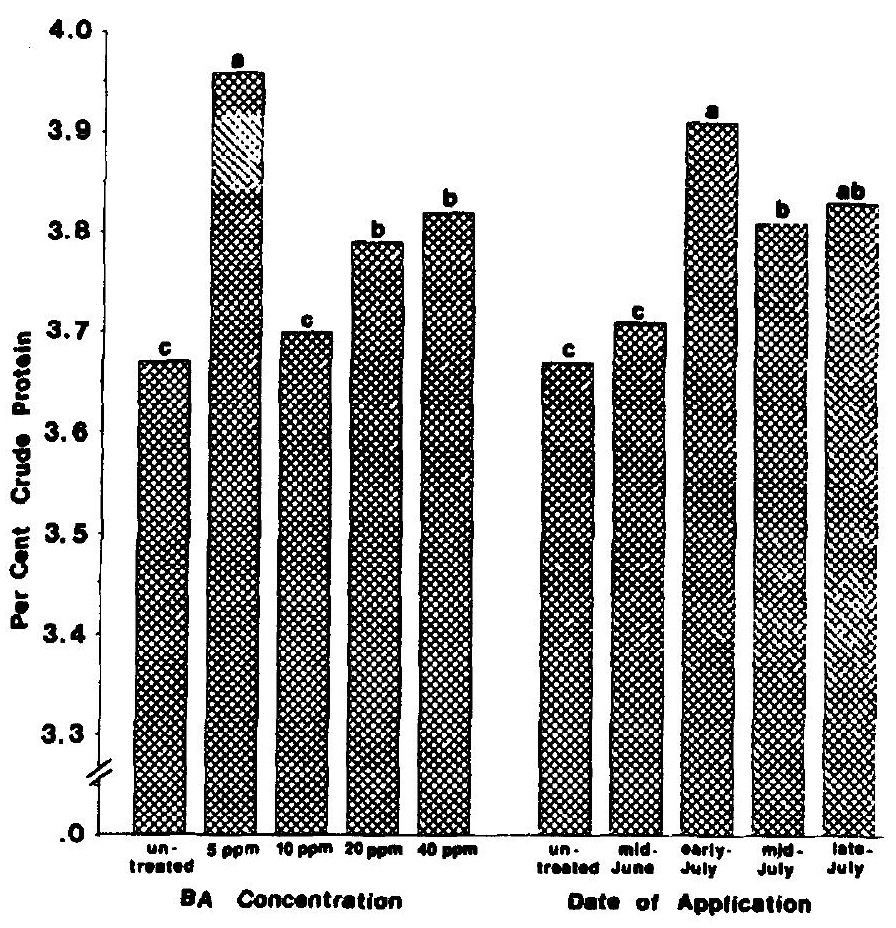

Fig. 2. Effect of BA applications averaged across dates and across concentrations on crude protein content of big bluestem leaves. Means with the same letter within each block do not differ significantly ( $\mathrm{P}>0.10)$.

(1971) also reported that cytokinins were most effective on bean plants if applied in the summer when endogenous levels were suboptimum.

Crude protein contents of BA-treated and untreated plants did not differ the first week in August. But thereafter plants treated with 5 ppm BA any time in July had more protein than untreated plants (Fig. 3). The transitory rise in protein content from 10 August to 17 August, corresponded with a week of cool temperatures and abundant rainfall. Crude protein also increased during the week of 24 August to 30 August, but that was unrelated to favorable climatic conditions. In that week, big bluestem treated with $5 \mathrm{ppm} \mathrm{BA}$ any time in July had significantly higher $(\hat{\alpha}<0.10)$ protein levels than untreated plants. That increase coincided with the time big bluestem normally translocates metabolites to its rhizomes (McKendrick et al. 1975). Thus, leaves receiving $5 \mathrm{ppm}$ BA could have been temporarily redirecting nutrients by acting as a stronger sink. Engelbrecht and Mothes (1961) observed that labelled amino acids applied to tobacco (Nicotiana tobacum) leaves accumulated in the root tips, by cytokinin added to the leaf prevented this mobilization.

The ability of BA to maintain high protein content in big bluestem leaves but not to retard chlorophyll loss appears contradictory. Morita (1980) observed that $85-95 \%$ of the nitrogen released from senescent rice (Oryza sativa) leaves originated from chloroplasts. The primary constituent of chloroplast nitrogen is the Calvin cycle enzyme ribulose bisphosphate carboxylase (RuBPCase)(Peterson and Huffaker 1975). Chlorophyll breakdown in big bluestem leaves suggests that BA did not inhibit proteolytic enzymes from hydrolyzing RuBPCase. However, BA apparently deferred the nitrogenous degradation products from being translocated out of the leaf. Fletcher et al. (1970) maintain that the ability of cytokinins to prevent effluent translocation of amino acids and sugars out of leaves is responsible for its antisenescent effect.

\section{Rhizome Crude Protein and TNC Content}

Crude protein and TNC contents of rhizomes from big bluestem receiving any $B A$ application did not differ from contents of untreated plants. That indicates that BA did not alter nitrogen and carbohydrate reserve cycles. 


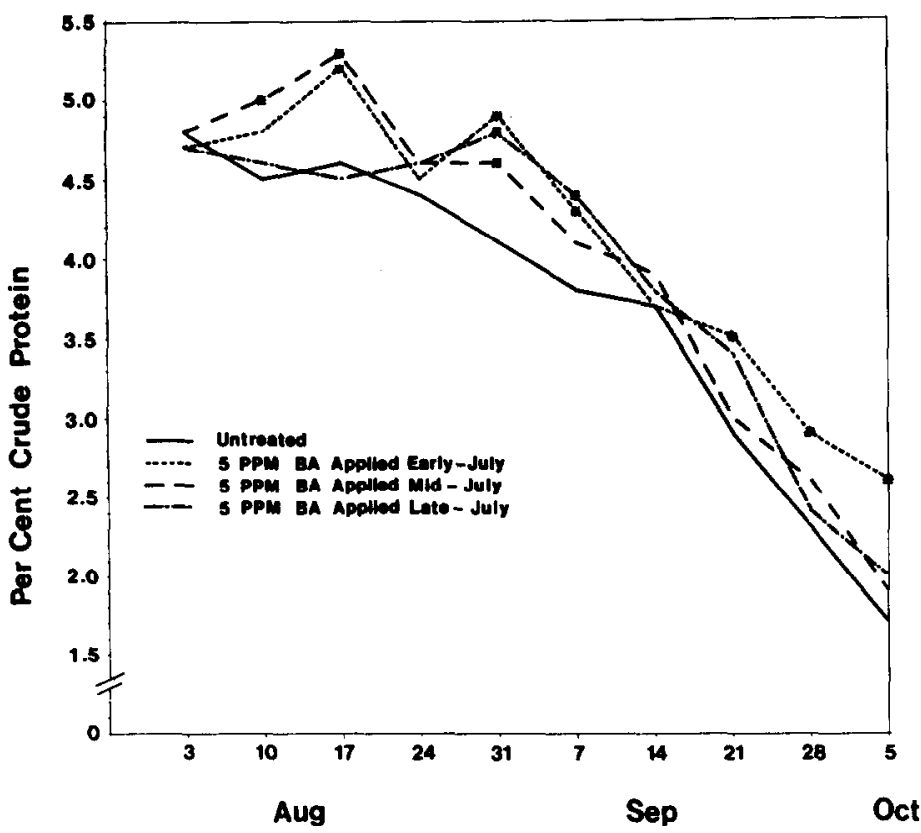

Fig. 3. Changes in crude protein content in untreated big bluestem leaves compared with changes in leaves treated with 5 ppm BA applied at indicated intervals. Asterisk above a given harvest date indicates a significant increase above untreated leaves $(\mathrm{P}<0.10)$.

Protein degradation and remobilization from the senescent leaf provides an important source of $\mathbf{N}$ for internal recycling. Rains et al. (1975) reported that replenishment of nitrogen reserves in big bluestem rhizomes begins in mid-August, coinciding with new root growth. Thus, delaying protein translocation from big bluestem leaves without affecting $\mathbf{N}$ reserves, suggests that the rhizome could be compensating for this loss with soil nitrogen uptake from new roots. Alternatively, big bluestem rhizomes may have imported nitrogenous compounds from the leaves after the October sampling date. McKendrick et al. (1975) reported that nitrogen and TNC from big bluestem shoots continued to accumulate in rhi7omes after frost, reaching a maximum in December.

\section{Herbage Yield}

Applying $5 \mathrm{ppm} \mathrm{BA}$ in either mid-or late-July significantly increased $(\hat{\alpha}<0.02)$ total herbage yields the next year over untreated plots (Fig. 4). Since plants were not segregated by species after clipping, we do not know if the increased yield was primarily from big bluestem or from other species. Other cytokinin concentrations and application dates had no effect on herbage production compared to untreated plots.

Biswas and Choudhuri (1977) found that $100 \mathrm{ppm}$ BA applied at any developmental stage in rice increased growth and dry matter accumulation. Apparently in big bluestem the response to exogenous cytokinin application has a carryover effect into the next year. That indicates that synthetic cytokinin can be cycled through the plant-storage organs and reactivated with the resurgence of growth.

\section{Literature Cited}

Arnon, D.I. 1949. Copper enzymes in isolated chloroplasts. Polyphenoleoxidase in Beta vulgaris. Plant Physiol. 24:1-15.

Biswas, A.K., and M.A. Choudhuri. 1977. Regulation of leaf senescence in rice by hormones sprayed at different developmental stages and its effect on yield. Indian J. Agr. Sci. 45:38-40.

Dalling, M.J., G. Boland, and J.H. Wilson. 1976. Relation between acid proteinase activity and redistribution of nitrogen during grain development in wheat. Aust. J. Plant Physiol. 3:721-730.

Engelbrecht, L., and K. Mothes. 1961. The effect of kinetin on the development of roots. Plant Cell Physiol. 2:271-276.

Fletcher, R.A. 1969. Retardation of leaf senescence by benzyladenine in intact bean plants. Planta. 89:1-8.

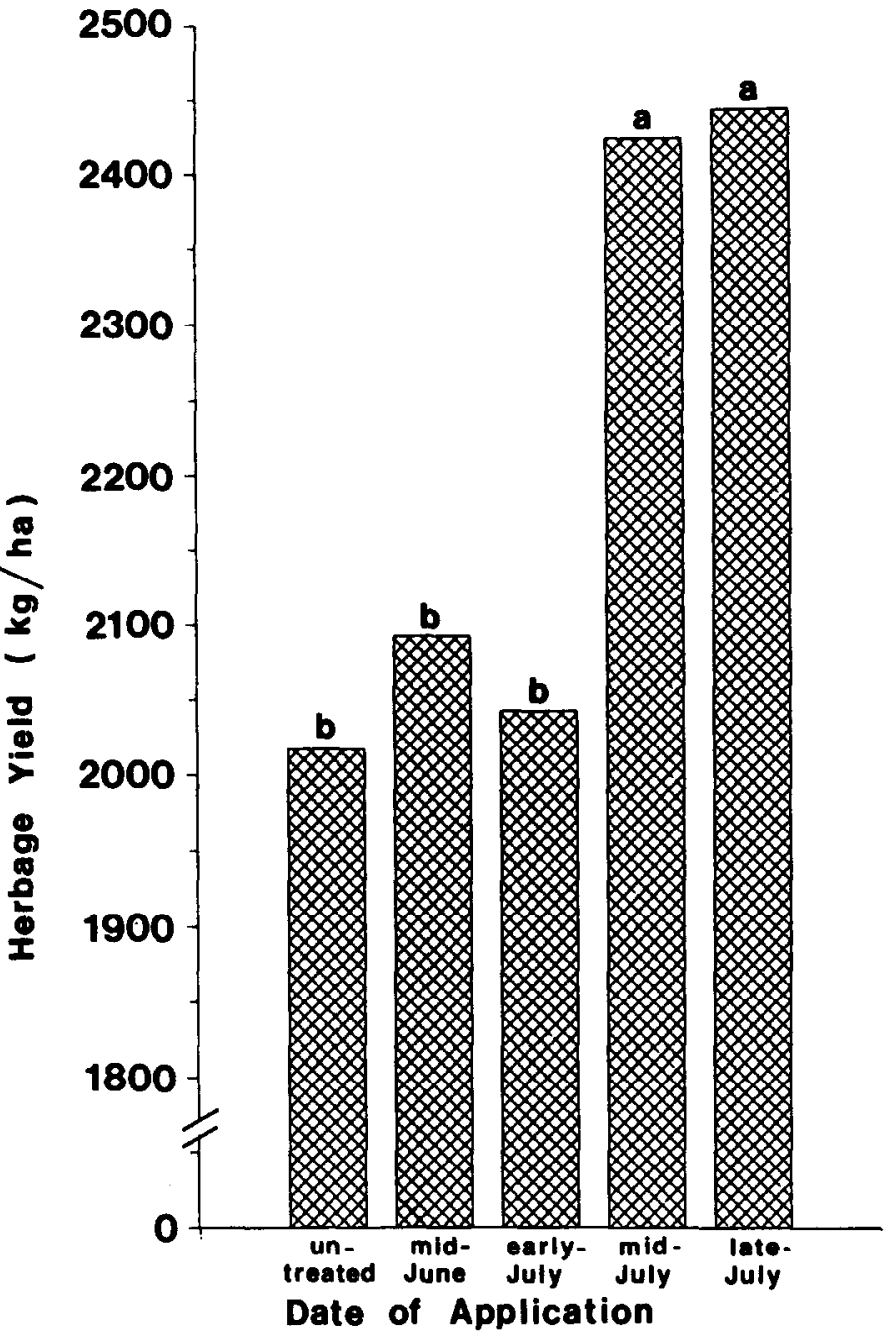

Fig. 4. Herbage yields (kg D. M./ha) of all species harvested at end of 1980 growing season, one year after applying 5 ppm BA on different dates. Means with the same letter do not differ significantly $(\mathbf{P}>0.10)$.

Fletcher, R.A., G. Hofstra, and N.O. Adadipe. 1970. Effects of benzyladenine on bean leaf senescence and the translocation of ${ }^{14} \mathrm{C}$-assimilates. Physiol. Plant. 23:1144-1148.

Mc Kendrick, J.D., C.E. Owensby, and R.M. Hyde. 1975. Big bluestem and indiangrass vegetative reproduction and annual reserve carbohydrate and nitrogen cycles. Agro-Ecosystems 2:75-93.

Morita, K. 1980. Release of nitrogen from chloroplasts during leaf senescence in rice (Oryza sativa L.). Ann. Bot. 46:297-302.

Naito, K., H. Tsuji, and I. Hatakeyama. 1978. Effect of benzyladenine on DNA, RNA, protein, and chlorophyll contents in intact bean leaves: Differential responses to benzyladenine according to leaf age. Physiol. Plant. 43:367-371.

Owensby, C.E. 1973. Modified step-point system for botanical composition and basal cover estimates. J. Range Manage. 26:302-303.

Peterson, I.W., and R.C. Huffaker. 1975. I.oss of ribulose 1, 5diphosphate carboxylase and increase in proteolytic activity during senescence of detached primary barley leaves. Plant Physiol. 55:1009. 1015.

Rains, J.R., C.E. Owensby, and K.E. Kemp. 1975. Effects of nitrogen fertilization, burning, and grazing on reserve constituents of big bluestem. J. Range Manage. 28:358-362.

Rao, M.R., L.H. Harbers, and E.F. Smith. 1973. Seasonal change in nutritive value of bluestem pastures. J. Range Manage. 26:419-422.

Richmond, A.E., and A. Lang. 1957. Effect of kinetin on protein content and survival of detached Xanthium leaves. Science. 125:650-651.

Richmond, A.E., B. Sachs, and D.J. Osbome. 1971. Chloroplasts, kinetin and protein synthesis. Physiol. Plant. 24:176-180.

Smith, D. 1969. Removing and analyzing total nonstructural carbohydrates from plant tissue. Univ. Wisconsin Res. Rep. No. 41.

Weinmann, H. 1942. The autumnal remigration of nitrogen and phosphorus in Trachypogon plusosus. J.S. Afr. Bot. 8:179-196. 